\title{
Aromatherapy for Relieving Chronic Pain in Community-Dwelling Older People: a Feasibility Study
}

\author{
Pau MML ${ }^{1 *}$, Suen LKP ${ }^{2}$ and Ho RML ${ }^{3}$ \\ ${ }^{1}$ School of Health Sciences, Caritas Institute of Higher Education, Hong Kong \\ ${ }^{2}$ School of Nursing, Hong Kong Polytechnic University, Hong Kong \\ ${ }^{3}$ Registered Nurse, Registered Midwife, Aromatherapist, Hong Kong
}

Submission: November 13, 2016; Published: November 14, 2016

*Corresponding author: Margaret PAU, School of Health Sciences, Caritas Institute of Higher Education, 18, Chui Ling Road, Tseung Kwan 0, New Territories, Hong Kong, Tel: (852) 36536767; Email: mpau@cihe.edu.hk

Abstract

Introduction: Chronic pain is a serious problem in the older population. Older people often seek complementary health approaches ( $\mathrm{CHA}$ ) to combat pain. Aromatherapy is a type of CHA with proven pain-relieving effect. This study aims to explore the effectiveness and acceptability of aromatherapy among Chinese community-dwelling older people who suffered from chronic pain.

Methodology: A convenience sample of 24 eligible community-dwelling older people in Hong Kong was recruited and randomly assigned to intervention or waitlist control group. The inclusion criteria were as follows: Chinese nationality, aged 60 years or above, cognitively intact, suffered from chronic pain for at least 6 months, and did not receive any complementary therapy over the past 3 months. The subjects received a 20-minute tailor-made aromatherapy massage with three kinds of essential oils (sweet marjoram, lavender, and eucalyptus) with pain relieving effects twice weekly for 4 weeks. The visual analogue scale (VAS) was used to assess pain, and the Pittsburgh Sleep Quality Index (PSQI) was used to evaluate the quality of sleep.

Results: Subjects in the experimental group exhibited reduced pain level and improved sleep condition after the therapy, even though the differences were not statistically significant. Almost all subjects did not know the type of aromatherapy before the study and agreed that the treatment was suitable for relieving pain in the older generation.

Conclusion: Aromatherapy is safe to older people and may relieve chronic pain and improve sleep condition. A larger scale study is recommended to explore the effect of the treatment.

Keywords: Aromatherapy; Chronic pain; Older people; Sleeplessness

Abbreviations: CHA: Complementary Health Approaches; AMT: Abbreviated Mental Test; VAS: Visual Analogue Scale; PSQI: Pittsburgh Sleep Quality Index; SPSS: Statistical Package for Social Sciences

\section{Introduction}

Older people often suffer from different kinds of pain associated with aging or other degenerative diseases. Chronic pain not only affects normal daily activities but also seriously compromises the quality of life. Analgesics are commonly used to alleviate pain but may cause common side effects upon prolonged use. As such, people often seek other therapies such as complementary health approaches (CHA) to combat chronic pain.

Chronic pain is defined as pain that lasts longer than 6 months; pain occurs with other disease symptoms and may be associated with fatigue, sleeplessness, and withdrawal from daily activities [1]. In Hong Kong, different kinds of pain are experienced by the older generation. In particular, pain caused by aging problems or degenerative diseases is experienced by the majority of older people and greatly affects their quality of life and everyday activities [2-4]. 
Aromatherapy, a type of CHA, is the art and science used to promote health holistically by using naturally extracted aromatic essences from plants [5]. It is well accepted and utilized by people who suffer from chronic pain to lessen their discomfort and aid their relaxation [6]. Healthcare professionals use aromatherapy in different settings to reduce pain and its related discomfort [7-10]. Thus far, few studies investigated the use of different methodologies and existing controversial findings. Hence, further studies must explore the effectiveness of aromatherapy in relieving chronic pain in older Chinese people to improve quality of life.

This study aims to evaluate the feasibility of aromatherapy in pain relief for community-dwelling older people in future largescale studies.

\section{Methods}

A convenience sample of 24 eligible community-dwelling older people in Hong Kong were recruited and randomly assigned to intervention or a waitlist control group.

The participants included must be Chinese, aged 60 years or above, able to communicate in Cantonese, have cognitively intact as assessed by the Abbreviated Mental Test (AMT) with a minimum score of 6 , suffering from chronic pain for at least 6 months even with regular medical follow-up or use of pain killers regardless of the route of application, and not receiving any complementary therapies over the past 3 months. Subjects that have language barrier or allergic histories to essential oil or perfumes were excluded.

Subjects in the intervention group received a 20-minute tailor-made aromatherapy massage by a qualified aroma therapist, depending on the site and duration of the pain the duration was two times per week for four weeks. A dilution of $1 \%$ of three essential oils (sweet marjoram, lavender, and eucalyptus) was mixed in almond oil to form the massage oil. Subjects in the waitlist control group also received the therapy in a similar fashion as the intervention group thereafter.

The Abbreviated Mental Test (AMT) was conducted during the recruitment period. It is a quick screening test that consists of 10 questions to assess the cognitive state of older Chinese people in this study. A score of less than 6 suggests a cognitive impairment [11]. Meanwhile, the geriatric pain scale using visual analogue scale (VAS) was used to assess pain. The VAS consists of a 10$\mathrm{cm}$ baseline, with the left-hand side as "no pain" and the righthand side as the "severe pain". The subject was asked to indicate on the line where the pain was in relation to the two extremes [12]. Furthermore, the Pittsburgh Sleep Quality Index (PSQI) was used to measure the quality of sleep of the participants. It was a 24-item questionnaire designed to assess the sleep quality and disturbances of a subject across a one-month time period. The total PSQI score ranged from 0 to 21, in which a PSQI score greater than 5 indicates poor sleep quality [13]. The baseline and post-intervention outcome measurements were conducted in the community center. Five exit questions were asked about the perceptions of aromatherapy after all aromatherapy sessions were completed. To achieve evaluator blinding, a research assistant who had no idea about the grouping was employed to conduct the assessments.

Ethical approval was sought prior to the study from the Ethics Committee of Caritas Institute of Higher Education and the participating elderly center. The purpose and procedure of the study were explained well to all the participants before signing of the consent form.

Descriptive statistics using Fisher's exact test $\mathrm{R}$ version (3.3.0) to describe the subjects' demographic characteristics. Wilcoxon signed-rank test was used for within group comparisons All other statistical analyses were using Statistical Package for Social Sciences (SPSS) version 23. A p-value of < 0.05 was considered statistically significant. The 'yes' or 'no' response from the exit questions were assigned with a code and transferred into a spreadsheet for calculation.

\section{Results}

Among the 24 subjects who participated in the study, 7 were males and 17 were females. Majority of them were over 80 years old $(79 \%)$. The most common site of pain was on both knees (25.9\%). There was no significant group difference in terms of gender, age distribution, marital status, educational background, and cognitive level, number of pain region, pain duration, and treatment received for pain relief (Table 1).

Table 1: Baseline socio-demographic variables of participants $(n=24)$.

\begin{tabular}{|c|c|c|c|c|}
\hline & $\underset{(n=24)}{\text { All }}$ & $\begin{array}{l}\text { Group1 } \\
(n=12)\end{array}$ & $\begin{array}{l}\text { Group } 2 \\
(n=12)\end{array}$ & Results * \\
\hline \multicolumn{5}{|l|}{ Gender } \\
\hline Male & 7 & 3 & 4 & $P=1.0$ \\
\hline Female & 17 & 9 & 8 & \\
\hline \multicolumn{5}{|l|}{ Age group } \\
\hline $60-69$ & 1 & 0 & 1 & \multirow{4}{*}{$\mathrm{P}=1.0$} \\
\hline $70-79$ & 3 & 2 & 1 & \\
\hline$>=80$ & 19 & 10 & 9 & \\
\hline Missing & 1 & 1 & 0 & \\
\hline \multicolumn{5}{|l|}{ Marital status } \\
\hline Single & 1 & 0 & 1 & \multirow[t]{2}{*}{$\mathrm{P}=1.0$} \\
\hline $\begin{array}{l}\text { Lived with family/ } \\
\text { friends }\end{array}$ & 23 & 12 & 11 & \\
\hline \multicolumn{5}{|l|}{$\begin{array}{l}\text { Educational } \\
\text { background }\end{array}$} \\
\hline Informal & 10 & 4 & 6 & \multirow{3}{*}{$P=0.6418$} \\
\hline Primary school & 10 & 6 & 4 & \\
\hline Secondary school & 4 & 2 & 2 & \\
\hline
\end{tabular}




\begin{tabular}{|c|c|c|c|c|}
\hline $\begin{array}{c}\text { Abbreviated mental } \\
\text { test } \\
\text { Mean (sd) }\end{array}$ & & $\begin{array}{c}9.17 \\
(1.34)\end{array}$ & $\begin{array}{c}9.08 \\
(1.31)\end{array}$ & $\begin{array}{c}\text { Mann- } \\
\text { Whitney U } \\
\text { test } \\
\mathrm{P}=0.630\end{array}$ \\
\hline Major pain site & & & & \multirow{6}{*}{$\begin{array}{c}\mathrm{P}=0.6668 \\
\text { (one region } \\
\text { vs more } \\
\text { than one } \\
\text { region) }\end{array}$} \\
\hline Waist and back & 1 & 0 & 1 & \\
\hline Knee & 7 & 4 & 3 & \\
\hline Hand and foot & 7 & 2 & 5 & \\
\hline Others & 1 & 1 & 0 & \\
\hline More than one region & 8 & 5 & 3 & \\
\hline Pain duration & & & & \multirow{5}{*}{$\mathrm{P}=0.7042$} \\
\hline Less than one year & 6 & 3 & 3 & \\
\hline 1 to 5 years & 13 & 7 & 6 & \\
\hline 6 to 10 years & 3 & 1 & 2 & \\
\hline More than 10 years & 2 & 1 & 1 & \\
\hline $\begin{array}{l}\text { Type of treatment } \\
\text { received (over the } \\
\text { past } 3 \text { months) }\end{array}$ & & & & \multirow{7}{*}{$\begin{array}{l}\quad \mathrm{P}=1 \\
\text { (no vs with } \\
\text { treatment) }\end{array}$} \\
\hline Nil & 6 & 3 & 3 & \\
\hline Oral pain killers & 8 & 2 & 6 & \\
\hline Topical application & 5 & 4 & 5 & \\
\hline CHA therapy & 0 & 0 & 0 & \\
\hline $\begin{array}{l}\text { Others, exercise } \\
\text { therapy }\end{array}$ & 1 & 0 & 1 & \\
\hline More than one type & 4 & 3 & 1 & \\
\hline
\end{tabular}

Group 1=Aromatherapy; Group 2=Waitlist control

* Fisher's exact test (unless indicated), using R version (3.3.0) (201605-03).

None of the subjects in the experimental group dropped out during the study, whereas one subject dropped out in the control group because of hospitalization. The mean attendance rate of the 12 sessions in the intervention group was $88.6 \%$ with 7 of them having $100 \%$ attendance. The reasons for the absence were mainly due to physical illnesses which were not directly associated with the nature of pain under attention. Furthermore, none of the subjects left the study due to adverse effect of the aromatherapy.

Even though no significant differences in the VAS and PSQI measurements before and after the intervention could be seen among the participants in both groups, subjects in the experimental group reported to have reduced pain level than the control group after the therapy (mean relative difference of 1.04 vs -0.50). In addition, the former also had an improved sleep condition after the therapy than the latter (mean relative difference of 0.17 vs -1.90 ) (Table 2).

Table 2: Within group comparison of different outcome variables.

\begin{tabular}{|c|c|c|c|c|}
\hline & Baseline & $\begin{array}{c}\text { Post- } \\
\text { intervention }\end{array}$ & & p-value \\
\hline & $\begin{array}{l}\text { Mean } \\
\text { (SD) }\end{array}$ & Mean (SD) & $\begin{array}{l}\text { Relative } \\
\text { difference }\end{array}$ & $\begin{array}{l}\text { (within } \\
\text { group } \\
\text { comparison } \\
\text { to the } \\
\text { baseline) } \dagger\end{array}$ \\
\hline \multicolumn{5}{|c|}{ Group 1: } \\
\hline \multicolumn{5}{|c|}{$\begin{array}{l}\text { Aromathearpy } \\
(\mathrm{n}=12)\end{array}$} \\
\hline VAS & $\begin{array}{c}4.50 \\
(2.47)\end{array}$ & $3.46(2.92)$ & $\begin{array}{c}1.04 \\
(2.97)\end{array}$ & 0.283 \\
\hline PSQI & $\begin{array}{c}8.08 \\
(3.55)\end{array}$ & $7.92(4.8)$ & $\begin{array}{c}0.17 \\
(2.82)\end{array}$ & 0.797 \\
\hline \multicolumn{5}{|c|}{ Group 2: } \\
\hline \multicolumn{5}{|c|}{$\begin{array}{l}\text { Waitlist } \\
\text { control } \\
(\mathrm{n}=12)\end{array}$} \\
\hline VAS & $\begin{array}{c}5.00 \\
(2.07)\end{array}$ & $5.91(3.58)$ & $\begin{array}{l}-0.50 \\
(3.57)\end{array}$ & 0.722 \\
\hline PSQI & $\begin{array}{c}7.80 \\
(4.59)\end{array}$ & $9.82(4.17)$ & $\begin{array}{l}-1.90 \\
(3.03)\end{array}$ & 0.078 \\
\hline
\end{tabular}

VAS $=$ Visual analogue scale $(0$ to $100 \mathrm{~mm}, 0 \mathrm{~mm}=$ no pain, $50 \mathrm{~mm}=$ moderate pain, $100 \mathrm{~mm}=$ severe pain)

PSQI = Pittsburgh sleep quality index (The total PSQI score ranges from 0 to 21, and a PSQI score greater than 5 indicates poor sleep quality)

† Within group comparisons using Wilcoxon Signed ranks test.

* Statistically significance $p<0.05$

Five dichotomous exit questions were asked after all sessions were completed. Among 23 subjects, 95.9\% did not know what aromatherapy was before the study. All subjects in the intervention group agreed that aromatherapy was good for 


\section{Journal of Complementary Medicine \& Alternative Healthcare}

relieving pain in the older generation and $83.3 \%$ of them would introduce this therapy to their friends. Moreover, all of them would like the elderly center to provide this service when the study was completed and $75 \%$ would enroll even if they needed to pay for it (Table 3).

Table 3: Exit questionnaire for the study.

\begin{tabular}{|c|c|c|c|}
\hline & Five exit questions & \multicolumn{2}{|c|}{$\mathbf{n = 2 3}$} \\
\hline & Yes (\%) & No (\%) \\
\hline 1 & $\begin{array}{c}\text { Do you know anything about } \\
\text { aromatherapy before the session? }\end{array}$ & 4.3 & 95.7 \\
\hline 2 & $\begin{array}{c}\text { Do you think aromatherapy is good to } \\
\text { elderly in relieving pain? }\end{array}$ & 87 & 13 \\
\hline 3 & $\begin{array}{c}\text { Will you introduce aromatherapy to } \\
\text { your friend to relieve pain? }\end{array}$ & 69.6 & 30.4 \\
\hline 4 & $\begin{array}{c}\text { Do you want to have aromatherapy if } \\
\text { the Centre provides this service later? }\end{array}$ & 87 & 13 \\
\hline 5 & $\begin{array}{c}\text { If the Centre provides this service } \\
\text { later, will you enroll if fees are } \\
\text { needed? }\end{array}$ & 69.6 & 30.4 \\
\hline
\end{tabular}

\section{Discussion}

All recruited subjects in the intervention group completed the whole program. This demonstrated that aromatherapy was well-accepted by this age group and older people nowadays are willing to accept new things. Although the results did not show a significant difference in the reduction of pain and improvement of sleep quality, most of the participants did express that this therapy could help release their pain. Based on this positive response, the use of aromatherapy as a method to relieve pain for the older people in Hong Kong should be considered.

In clinical aromatherapy, the selection and blending of the essential oils were usually tailor-made for all the clients with specific purposes. In this study, sweet marjoram, lavender, and eucalyptus were selected. Sweet marjoram is used to relieve muscle or joint pain, as well as soft tissue trauma; its sweet fragrance also possesses a calming effect. Lavender has a strong evidence for its stress relieving function; it is also used as an analgesic and anti-inflammatory. Eucalyptus is used to relieve aches, muscle pain, and respiratory congestion. All three oils were well-tolerated on the skin and were mixed in almond oil, which is moisturizing and suitable for older people [14]. There was no report of any adverse effect during or after the treatment, indicating that this was safe to the older population. Since pain is strongly associated with sleep difficulties in older people [15], the therapeutic effects of this selection of oil might improve their sleep quality.

For the exit questions, majority felt the effect of aromatherapy and would recommend its use to their friends. In fact, the center organized regular aromatherapy sessions for the members after the completion of this study. Thus, this outcome strongly suggested that both the staff and older people accepted this CHA and demonstrated its popularity as well.

\section{Conclusion}

Preliminary findings from this feasibility study indicated that aromatherapy may have an effect on relieving chronic pain and improving sleep condition of the community-dwelling older people. It is well-accepted by them with no reported adverse effect. However, a bigger sample size should be considered in future studies to establish the causal relationship between the treatment and its effect.

\section{Acknowledgement}

We extend our appreciation to Professional Development Fund of the Hong Kong Nursing Association and HKSKHWC \& Western District Day Care Centre for the Elderly and subjects for their sincere support to this study.

\section{References}

1. http://www.webmd.com/pain-management/guide/understandingpain-management-chronic-pain

2. Qian C, Hayman Laura L, Shmerling Robert H, Bean Jonathan F, Leveille Suzanne G (2011) Characteristics of Chronic Pain Associated with Sleep Difficulty in Older Adults: The Maintenance of Balance, Independent Living, Intellect, and Zest in the Elderly (MOBILIZE) Boston Study. Journal of the American Geriatrics Society 59(8): 1385-1392.

3. http://onlinelibrary.wiley.com/doi/10.1111/j.1532-541 5.2011.03544.x/abstract

4. Kress H, Ahlbeck K, Aldington D, Alon E, Coaccioli S, et al. (2014) Managing chronic pain in elderly patients requires a CHANGE of approach. CMRO 30(6): 1153-1164.

5. Tse M, Wan V, Wong A (2013) Pain and pain-related situations surrounding community-dwelling older persons. J Clin Nurs 22(1314): 18701879 .

6. National Association for Holistic Aromatherapy, Exploring Aromatherapy.

7. Karadag E, Samancioglu S, Ozden D, Bakir E (2015) Effects of aromatherapy on sleep quality and anxiety of patients Nursing in Critical Care. Nurs Crit Care.

8. Kaviani M, Azima S, Alavi N, Tabaei MH (2014) The effect of lavender aromatherapy on pain perception and intrapartum outcome in primiparous women. BJM 22(2): 125-128.

9. Satou T, Chikama Y, Hachigo M, Urayama H, Murakami S, et al. (2013) Effect of aromatherapy massage on elderly patients under long-term hospitalization in Japan. The Journal of Alternative and Complementary Medicine 19 (3): 235-237.

10. Bagetta G, Cosentino M, Sakurada T (2015) Aromatherapy: Basic Mechanisms and Evidence Based Clinical Use ( $1^{\text {st }}$ edn $)$, CRC Press, New York.

11. Tang SK, Tse MY (2014) Aromatherapy: Does It Help to Relieve Pain, Depression, Anxiety, and Stress in Community-Dwelling Older Persons? BioMed Research International 1-12.

12. Chu LW, Pei CKW, Ho MH, Chan PT (1995) Validation of the abbreviated mental test (Hong Kong version) in the elderly medical patient. Hong Kong Medical Journal 1(3): 207-211.

13. Wewers ME, Lowe NK (1990) A Critical Review of Visual Analogue Scales in the Measurement of Clinical Phenomena. Res Nurs Health 13(4): 227-236. 
14. Buysse DJ, Reynolds CF, Monk TH, Berman SR, Kupfer DJ (1989) The Pittsburgh Sleep Quality Index (PSQI): A New Instrument for Psychiatric Research and Practice. Psychiatry Res 28(2): 193-213.

15. Rhind J (2012) Essential Oils: A Handbook for Aromatherapy Practice. ( $2^{\text {nd }}$ edn), Jennifer Peace Rhind with David Pirie, Jessica Kingsley Publishers, UK.
16. Chen Q Hayman LL, Shmerling RH, Bean JF, Leveille SG (2011) Characteristics of Chronic Pain Associated with Sleep Difficulty in Older Adults: The Maintenance of Balance, Independent Living, Intellect, and Zest in the Elderly (MOBILIZE) Boston Study. Journal of the American Geriatrics Society 59(8): 1385-1392.

Your next submission with JuniperPublishers will reach you the below assets

- Quality Editorial service

- Swift Peer Review

- Reprints availability

- E-prints Service

- Manuscript Podcast for convenient understanding

- Global attainment for your research

- Manuscript accessibility in different formats ( Pdf, E-pub, Full Text, Audio)

- Unceasing customer service

Track the below URL for one-step submission https://juniperpublishers.com/submit-manuscript.php 